Jurnal Care Vol .5, No2,Tahun 2017

\title{
STUDI KASUS SARANA TERAPI OKUPASI DENGAN TAMAN EDUKASI PADA PENDERITA AUTIS DI SLB SUMBER DHARMA KOTA MALANG
}

\author{
Wahidyanti Rahayu Hastutiningtyas ${ }^{1}$, Irawan Setyabudi ${ }^{2}$ \\ Universitas Tribhuwana Tunggadewi Malang \\ e-mail: abc_1yanti@yahoo.com
}

\begin{abstract}
Occupational therapy is a type of therapy that is specifically used to help children to live independently with a variety of existing health conditions. This therapy is used as part of a treatment program for children with an illness, such as delayed developmental birth, psychological problems, or long-term injury. The research was conducted by qualitative method by deductive and inductive description. Nasution (2004) mentions that descriptive research is a method of researching the setatus of a group of people, an object, a set of conditions, a thought system, or a class of events in the present. The purpose of this descriptive research is to make deskipsi, picture or painting in a systematic, factual and accurate about the facts, properties and relationships between the phenomena investigated. The results of this study see the occupational facilities by using an educational park in one of the SLB Kota Malang. Educational parks in schools include several zones of therapy and education. Parks used for children with autism include the concept of shape, circulation, and vegetation. Educational park can be used as a means of occupational therapy where there are objects of therapy that include physical and mental. The form of activities performed in the SLB is a form of game using therapy in the form of play to provide fun and good socialization. The stages of occupational therapy, among others: (1) Evaluation Stage, (2) Intervention Stage and (3) Final Results Stage. The phase of occupational therapy of the group can be done by (1) Orientation, (2) Introduction stage, (3) Warm-up activities, (4) Selected activity stage and (5) Termination Phase.
\end{abstract}

Keywords: Occupational Therapy, Education Park and Autism

\begin{abstract}
ABSTRAK
Terapi okupasi adalah jenis terapi yang secara khusus digunakan untuk membantu anak untuk hidup mandiri dengan berbagai kondisi kesehatan yang telah ada. Terapi ini digunakan sebagai bagian dari program pengobatan untuk anak yang mengidap suatu penyakit, seperti keterlambatan perkembangan sejak lahir, masalah psikologis, atau cedera jangka panjang. Penelitian dilakukan dengan metode kualitatif dengan cara deskripsi deduktif dan induktif. Nasution (2004) menyebutkan bahwa penelitian deskriptif adalah suatu metode dalam meneliti setatus sekelompok manusia, suatu obyek, suatu set kondisi, suatu sistem pikiran, ataupun suatu kelas peristiwa pada masa sekarang. Tujuan dari penelitian deskriptif ini adalah untuk membuat deskipsi, gambaran atau lukisan secara sistematis, faktual dan akurat mengenai fakta-fakta, sifat-sifat serta hubungan antar fenomena yang diselidiki. Hasil penelitian ini melihat sarana okupasi dengan menggunakan taman edukasi di salah satu SLB Kota malang. Taman edukasi yang ada disekolah meliputi beberapa zona terapi dan pembelajaran. Taman yang digunakan untuk anak autis meliputi konsep bentuk, sirkulasi, dan vegetasi. Taman edukasi dapat digunakan sebagai sarana
\end{abstract}


terapi okupasi dimana terdapat objek terapi yang meliputi fisik dan mental. Bentuk kegiatan yang dilakukan di SLB adalah berupa permainan dengan menggunakan terapi yang berbentuk bermain untuk memberikan kesenangan dan sosialisasi yang baik. Adapun tahapan terapi okupasi, antara lain: (1) Tahap Evaluasi, (2) Tahap Intervensi dan (3) Tahap Hasil Akhir. Tahap terapi okupasi kelompok dapat dilakukan dengan (1) Orientasi, (2) Tahap Pendahuluan (Introduction), (3) Tahap pemanasan (Warm-up activities), (4) Tahap aktivitas terpilih (selected activities) dan (5) Tahap Terminasi.

Kata Kunci : Terapi Okupasi, Taman Edukasi dan Autis

\section{PENDAHULUAN}

Terapi okupasi adalah jenis terapi yang secara khusus digunakan untuk membantu anak untuk hidup mandiri dengan berbagai kondisi kesehatan yang telah ada dengan cara memberikan kesibukan atau aktivitas sehingga anak akan fokus untuk mengerjakan sesuatu. Terapi ini digunakan sebagai bagian dari program pengobatan untuk anak yang mengidap suatu penyakit, seperti keterlambatan perkembangan sejak lahir, masalah psikologis, atau cedera jangka panjang. Tujuan utama terapi okupasi adalah untuk membantu meningkatkan kualitas hidup anak dalam memaksimalkan kemandirian.

Anak Berkebutuhan Khusus atau ABK, merupakan istilah untuk seseorang yang memiliki kekurangan fisik ataupun mental. Salah satu wujud kekurangan mental adalah autis. Adapun gejala yang tampak adalah ketidakpedulian terhadap lingkungan sekitar, seperti menolak berinteraksi karena fokus teralihkan pada suatu hal sehingga terkesan hidup dalam dunianya sendiri. Bagi anak autis, terkadang sulit untuk berkomunikasi secara verbal dan ada kecenderungan kelainan persepsi sensorisnya. Sebagai upaya untuk merubah keadaan agar lebih baik, diperlukan terapi yang melibatkan ruang sekitar. Terapi aktivitas adalah upaya untuk mengalihkan kesibukan bagi anak autis dengan mengerjakan sesuatu yang lain agar mengembalikan fokus, seringkali disebut dengan terapi okupasi. Di sekolah, terdapat ragam aktivitas yang bisa dikerjakan anak autis seperti pembelajaran luar ruang dan bermain. (Haliimah, et al, 2014). Potensi ini secara arsitektural dapat diambil untuk perencanaan organisasi ruang agar anak bisa belajar dan bermain secara optimal, seperti ada area taman untuk terapi menanam, merawat dan memetik tanaman hortikultura atau terapi untuk mendengarkan kicauan dan suara air 
Jurnal Care Vol .5, No2,Tahun 2017

mancur. Terapi didasarkan untuk kepekaan panca indera. Peran ruang terbuka sebagai taman sebagai sarana belajar, bermain dan sarana terapi yang diperlukan untuk siswa autis.

Pengaruh ruang luar sebagai taman edukasi terhadap perkembangan anak disampaikan oleh beberapa ahli, seperti disebutkan oleh Ramadhani (2016), bahwa salah satu bentuk pembelajaran adalah memberikan pengalaman langsung, sehingga siswa lebih mudah memahami. Contohnya adalah saat mata pelajaran IPA, siswa secara langsung dapat memahami karakter tanaman yang tumbuh di taman. Siswa dengan inderanya dapat melihat, meraba, merasakan tanaman. Aspek ini, taman berfungsi sebagai edukasi. Lauren (2012), menyebutkan bahwa ruang terbuka seringkali digunakan sebagai taman bermain anak dengan fasilitas pendukungnya. Aktivitas tersebut termasuk edukatif, yang mana usia anak yang masih muda dapat peka terhadap rangsangan dari lingkungannya. Baskara (2011) dalam penelitiannya juga membahas tentang taman untuk edukasi anak-anak, mampu untuk membangkitkan sisi kognitif, sosial, fisik, serta kemampuan emosi yang diperlukan saat dewasa. Penyediaan fasilitas tentu harus dipertimbangkan pada sisi keamanan dan keselamatannya, seperti penggunaan material yang tidak berbahaya atau vegetasi yang tidak beracun.

Sebagai sarana terapi untuk siswa autis, taman harus memberikan suatu manfaat perubahan. Taman dikembangkan dengan konsep sensori atau berhubungan dengan panca indera. Adapun Haliimah (2014), menyebutkan bahwa sistem sensori dalam tubuh ada vestibular (gerakan keseimbangan), proprioceptive (ototmotorik), visual (penglihatan), auditory (pendengaran), tactile (peraba), gustatory (pengecap), dan olfactory (penciuman). Berdasarkan konsep ini, taman dibedakan menjadi area bermain (ayunan dan perosotan), area taman yang merangsang visual seperti warna cat yang kontras atau pemilihan jenis tanaman dengan bunga warna-warni, area taman yang merangsang pendengaran seperti kicauan burung dan air mancur, area taman yang merangsang indera pengecap yaitu ada buah siap petik seperti jeruk dan tomat, dan area taman yang merangsang penciuman dengan aroma bunga, seperti lavender atau melati. 
Jurnal Care Vol .5, No2,Tahun 2017

\section{METODE PENELITIAN}

Penelitian dilakukan dengan metode kualitatif dengan cara deskripsi deduktif dan induktif. Nasution (2004) menyebutkan bahwa penelitian deskriptif adalah suatu metode dalam meneliti sekelompok manusia, suatu obyek, suatu set kondisi, suatu sistem pikiran, ataupun suatu kelas peristiwa pada masa sekarang. Tujuan dari penelitian deskriptif ini adalah untuk membuat deskipsi, gambaran atau lukisan secara sistematis, faktual dan akurat mengenai fakta-fakta, sifat-sifat serta hubungan antar fenomena yang diselidiki. Penelitian ini diawali dari studi inventarisasi atau pendataan unsur hardscape dan softscape sebagai data primernya, berupa wawancara dan rekaman. Berikutnya akan dilakukan analisis-sintesis potensi dan kendala dalam penerapan terapi okupasi. Hasil penelitian ini lebih pada manfaat sarana terapi okupasi sebagai taman ekukasi pada SLB Sumber Dharma Malang. Menurut Haliimah, et al (2014), penderita autis adalah penderita gangguan pengolahan informasi sensoris akibat kelainan pada sistem sarafnya sehingga dapat diberikan taman edukasi yang berfokus pada konsep sensory garden. Karakteristik terapi edukasi adalah adanya ruang edukasi, penggunaan elemen kerasa dan lunak serta adanya ruang untuk bermain. Taman dengan konsep sensory garden sebagai terapi anak autis meliputi terapi panca indera pengecap, penglihat, penciuman, peraba dan pendengaran (Prabowo, 2015).

Data primer yang diperoleh pada penelitian ini digunakan dengan wawancara dan rekaman. Proses wawancara melibatkan beberapa guru dan wali murid yang berkaitan dengan penggunaan taman, khususnya Ibu Pur dan Ibu Nifta selaku guru SMPLB. Studi kasus dilakukan di Sekolah Luar Biasa (SLB) Sumber Dharma Malang, alasannya adalah lokasi berada dalam kota jauh dari pusat keramaian dengan suasana tenang, berpotensi untuk dikembangkan taman dengan konsep baru karena taman sebelumnya hanya terdapat penataan pot dan area bermain anak.

\section{HASIL}

Studi kasus SLB Sumber Dharma berada di Jalan Jago Malang, yang tidak jauh dari Pasar Blimbing. Sekolah dikelilingi oleh permukiman warga dan aksesnya masuk pada gang dengan lebar jalan 4 meter. 
Jurnal Care Vol .5, No2,Tahun 2017

Bangunan sekolah terdiri atas 2 lantai yang memiliki ruang terbuka yang terbatas. Luas total tanah adalah $576 \mathrm{~m}^{2}$ yang terbagi atas luas bangunan dan taman. Taman pada sekolah ada pada taman depan dan tengah. Taman depan dengan panjang 17 meter dan lebar 4 meter, atau $62 \mathrm{~m}^{2}$ setelah dikurangi luas teras, sedangkan taman tengah memiliki dimensi panjang 14 meter dan lebar 4 meter atau luasannya $56 \mathrm{~m}^{2}$. Pengajar terdiri atas guru 15 orang dan siswa dengan total 47 anak yang terbagi atas 5 anak TKLB, 25 anak SDLB, 8 anak SMPLB, dan 9 anak SMALB. Ruangan yang tersedia ada 7 ruang kelas dan terdapat fasilitas laboratorium dan perpustakaan. Menurut ibu Nifta, selaku kepala sekolah SMPLB jumlah anak autis tidak sebanyak anak tuna grahita, namun kecenderungan perilaku mereka hampir sama seperti anak-anak usia kelas 5 SD dan kurang fokus.

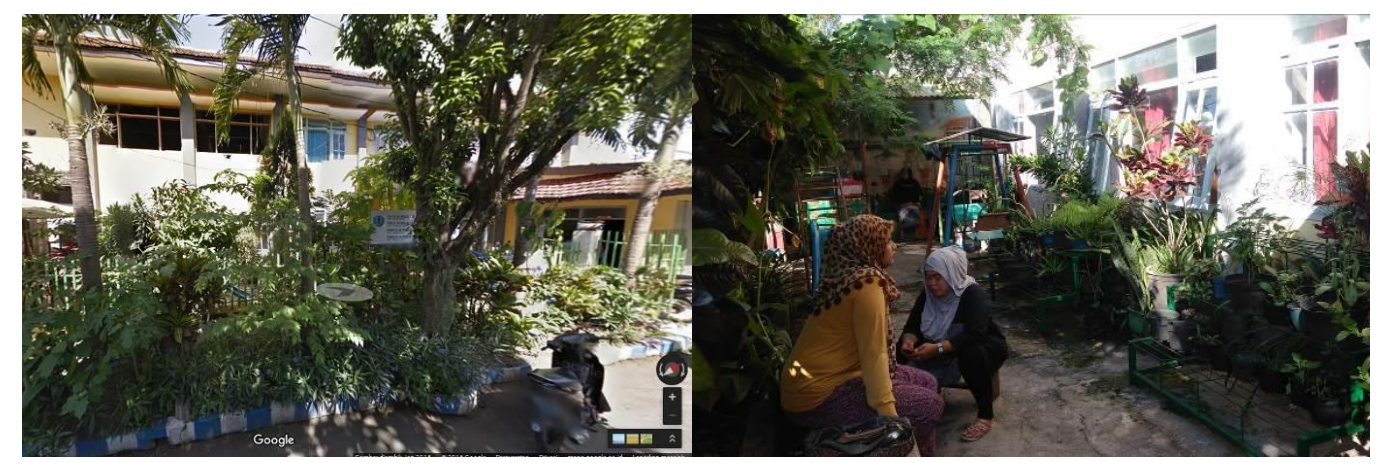

Gambar 1. (kiri)Ffoto tampak depan SLB Sumber Dharma, (kanan) foto lokasi taman depan

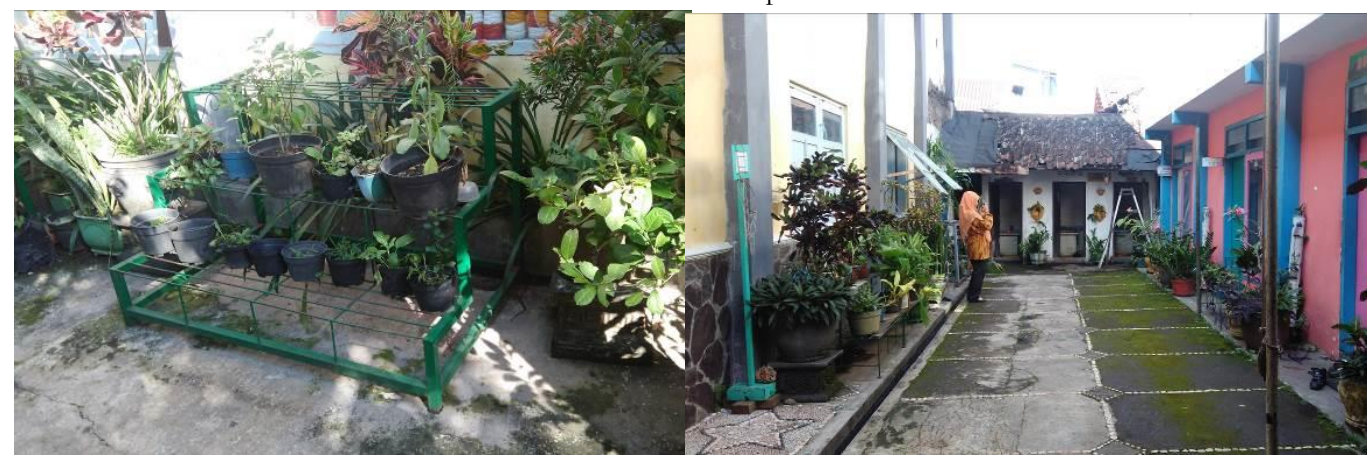

Gambar 2. (kiri) Taman dengan bentuk pot bertingkat, (kanan) foto lokasi taman tengah 
Taman pada SLB ini dibagi menjadi dua yaitu taman depan dan taman tengah. Taman depan untuk area parkir sepeda, area bermain, berkebun dan tempat duduk orang tua yang akan menjemput. Tanaman yang ada sudah banyak ragamnya seperti tanaman hias, tanaman rak, taman vertikultur, dan pohon peneduh. Adapun tanamannya adalah puring, kamboja, drasena, lidah buaya, kopi, manisa, sawo, buah naga, pucuk merah, kuping gajah, palem, lamtoro, temulawak, kol banda, jeruk, cabe, jambu, dan sebagainya. Menurut ibu Nifta, pengembangan taman depan untuk area buah-buahan. Berikutnya adalah taman tengah, yang memiliki fungsi sedikit berbeda. Taman tengah digunakan untuk upacara sehingga dibutuhkan ruang bebas. Area taman dimampatkan ke dekat dinding dengan pengembangan secara vertikal. Adapun tanaman yang ada adalah puring, kamboja, adam hawa, kol banda, terong, temu lawak, sansivera, beras kutah, suruh dan drasena. Penataan taman masih belum teratur sehingga dalam pengembangannya lebih sesuai dengan tanaman sayur-sayuran dan hortikultura.
Pengguna taman terbatas pada guru, siswa, orang tua siswa, dan tamu. Taman depan merupakan area yang masih bisa diakses oleh orang tua siswa sedangkan taman tengah bersifat privat karena hanya terbatas pada guru dan siswa. Umumnya area taman digunakan pada pagi sampai siang hari pada jam tertentu seperti sebelum masuk, saat istirahat ataupun pulang sekolah. Namun secara umum taman masih kurang difungsikan. Berdasarkan hasil wawancara dengan narasumber salah satu guru yaitu ibu Christina Sri Purwatiningsih (Ibu Pur) selaku guru SMPLB, taman yang diharapkan adalah bersifat teduh, melibatkan siswa dalam proses penanaman ataupun mata pelajaran yang bertema, dan prioritas taman depan karena penyinaran maksimal diperoleh pada depan bangunan. Beberapa wali murid sebagai pengguna taman; yang sedang duduk dan menunggu untuk menjemput anaknya; mengatakan bahwa kondisi awal taman sebenarnya sudah nyaman dengan banyak teduhan namun kurang dimanfaatkan untuk kegiatan bermain siswa. Kondisi ini diperlukan adanya perubahan sehingga taman bisa menampung kegiatan yang aktif. Pengguna utamanya adalah siswa dari berbagai tingkatan kelas dan terbagi atas 
beberapa tuna, yaitu tuna grahita, tuna rungu dan autis. Tema taman memang ditujukan pada anak autis tetapi juga bisa untuk tuna yang lain karena taman sensorik mampu merangsang panca indera untuk terapi dan edukasi.

Menurut Wahyuni (2015) konsep taman sensorik dibagi menjadi dua bagian yaitu hiposensitif dan hipersensitif. Taman terapi hiposensitif ditujukan untuk anakanak agar lebih aktif, berbentuk tegas, ada area bermain yang cukup luas. Taman terapi hipersensitif ditujukan untuk-anak yang terlalu aktif bergerak agar lebih tenang. Area taman yang dikembangkan dengan pola lunak dan melingkar, fitur air berirama rendah untuk efek menenangkan.

Taman edukasi menurut Ramadhani (2016) merupakan pemanfaatan taman sebagai media untuk pembelajaran dengan menggunakan pengalaman secara langsung, sehingga siswa lebih mudah untuk mempelajari. Adapun contohnya adalah pengenalan tumbuhan pada pelajaran IPA dengan melihat objeknya langsung berada di taman. Lauren (2012) juga menyebutkan bahwa ruang terbuka atau taman sering digunakan sebagai taman bermain dengan segala fasilitas pendukungnya. Dalam taman, selain dikembangkan aspek rekreatifnya juga edukatifnya karena usia anak masih muda dan peka terhadap rangsangan yang berasal dari lingkungan, khususnya bagi anak autis dan tuna grahita.

\section{PEMBAHASAN}

Penelitian ini melihat potensi pengembangan terapi okupasi pada studi kasus terpilih pada SLB Sumber Dharma Malang. Taman yang dikembangkan dengan tema taman edukasi bagi anak difabel dengan wujud taman sensorik. Berdasarkan informasi dari guru bahwa anak-anak autis dapat distimulus untuk kondisi yang lebih baik dengan membentuk taman tematik. Taman sensorik yang dimaksudkan adalah terapi yang dibagi menjadi zona tertentu untuk merangsang panca indera. Berikut adalah kriterianya yang dijelaskan oleh Prabowo (2015) : (a) indera penglihatan, penggunaan warna pada tanaman seperti bunga dan buah yang mencolok, (b) indera pengecap, tanaman yang disediakan bisa langsung dipetik dan dimakan seperti jeruk, tomat dan belimbing, (c) indera penciuman, adanya tanaman beraroma wangi seperti lavender 
dan rose, (d) indera peraba, penggunaan bahan bangunan pada alur jalan yang berbeda teksturnya, (e) indera pendengaran, menyediakan area burung berkicau dan suara air mancur. Dengan adanya area sensorik ini dapat melatih tingkat kefokusan dari anak-anak autis.

Lebih spesifik tentang konsep taman edukasi dan terapi untuk anak autis pada SLB Sumber Dharma sebagai berikut,

a. Konsep ruang dibagi menjadi 2 jenis yaitu untuk autis hiposensitif dan hipersensif. Perbedaannya, hiposensitif disediakan ruang untuk melatih keaktifan seperti area bermain aktif (perosotan, ayunan, dan sebagainya) yang dinilai aman. Hipersensitif perlu disediakan taman yang menenangkan seperti adanya area teduhan berupa pohon atau gazebo. Alur ruang secara linear atau mengarahkan siswa untuk merasakan ruangan secara urut. Taman hiposensitif berada di taman depan dengan eksisting tempat bermain dan penataan tanaman, taman hipersensitif berada di ruang tengah karena suasana lebih tenang. b. Taman terapi sensorik, area taman dibagi menjadi taman untuk merangsang visual, pengecap, penciuman, peraba dan pendengaran. Adapun penerapan konsep taman sensorik dapat berpengaruh terhadap perilaku anak siswa yang sebelumnya memiliki dunia sendiri menjadi lebih fokus terhadap sesuatu, seperti warna, rasa, bau, tekstur dan suara.

c. Sebagai taman edukasi, taman sebagai aplikasi mata pelajaran dengan pengenalan jenis tanaman (outdoor learning process) dan disediakan area bercocok tanam untuk belajar merawat, menyiram dan memanen.

Taman edukasi dapat digunakan sebagai sarana terapi okupasi dimana terdapat objek terapi yang meliputi fisik dan mental. Fisik dapat memberikan terapi yang membantu melatih gerakan kaki dan atau tangan. Misalnya saja dengan lempar bola, menendang bola, dan sebagainya. Mental dapat memberikan terapi yang dapat melatih dan mengembangkan bakat, kreativitas dan rasa percaya diri. Bentuk kegiatan yang dilakukan di SLB adalah berupa permainan dengan menggunakan terapi yang berbentuk bermain untuk memberikan kesenangan dan sosialisasi yang baik. Misalnya dengan 
bermain lempar bola, bermain tebak kata, dan sebagainya.

Terapi okupasi secara individu dapat dilaksanakan pada taman atau area outdoor dengan beberapa tahapan berikut. Menurut Tirta \& Putra (2008) dan Untari (2006). Adapun tahapan terapi okupasi, antara lain:

a. Tahap Evaluasi

Tahap evaluasi sangat menentukan bagi tahap-tahap berikutnya. Pada tahap awal ini mulai dibentuk hubungan kerjasama antara guru dan anak, yang kemudian akan dilanjutkan selama tahap terapi okupasi. Tahap ini juga disebut tahapan kognitif yang memfokuskan kemampuan pekerjaan yang berorientasi pada keterampilan kognitif. Tahap evaluasi dibagi menjadi 2 langkah. Langkah pertama adalah profil pekerjaan (occupational profile) dimana guru mengumpulkan informasi mengenai riwayat pola hidup sehari-hari, minat, dan kebutuhannya. Langkah kedua adalah analisa tampilan pekerjaan (analysis of occupational performance). Tampilan pekerjaan yang dimaksud adalah kemampuan untuk melaksanakan aktivitas dalam kehidupan keseharian, yang meliputi aktivitas dasar hidup seharihari, pendidikan, bermain, mengisi waktu luang, dan partisipasi sosial. Hal yang juga diperhatikan pada tahap awal atau kognitif ini adalah membangkitkan ide saat waktu luang, mempelajari berapa banyak kemungkinan atau waktu yang dihabiskan, membandingkan beberapa kegiatan yang menyenangkan dibanding bekerja, mengatur waktu untuk hal yang menyenangkan (kebutuhan, pilihan, hambatan, dan minat), dan mengatur waktu diri sendiri. Keterampilan dasar yang diharapkan mendapatkan keterampilan, memproses keterampilan, menyalurkan keterampilan, dan ketegasan. Guru menanyakan kebiasaan sehari-hari dan memberikan pengetahuan tentang tanaman pada siswa, khususnya pada mata pelajaran IPA.

\section{b. Tahap Intervensi}

Tahap intervensi yang terbagi dalam 3 langkah, yaitu rencana intervensi, implementasi intervensi, dan peninjauan (review) intervensi. Rencana intervensi adalah sebuah rencana yang dibangun berdasar pada hasil tahap evaluasi dan menggambarkan pendekatan terapi okupasi serta jenis intervensi yang terpilih, guna mencapai target hasil akhir yang ditentukan. Rencana intervensi ini dibangun secara bersama-sama dengan anak (termasuk pada beberapa kasus bisa bersama keluarga atau orang lain yang 
berpengaruh), dan berdasarkan tujuan serta prioritas anak. Rencana intervensi yang telah tersusun kemudian dilaksanakan sebagai implementasi intervensi yang mana diartikan sebagai tahap keterampilan dalam mempengaruhi perubahan tampilan pekerjaan anak, membimbing mengerjakan pekerjaan atau aktivitas untuk mendukung partisipasi. Langkah ini adalah tahap bersama antara anak, ahli, dan asisten terapi okupasi. Implementasi intervensi terapi okupasi dapat dilakukan baik secara individual maupun berkelompok, tergantung dari keadaan siswa, tujuan terapi, dan lain-lain. Metode individual bertujuan untuk mendapatkan lebih banyak informasi dan sekaligus untuk evaluasi anak, pada anak yang belum dapat atau mampu untuk berinteraksi dengan cukup baik didalam suatu kelompok sehingga dianggap akan mengganggu kelancaran suatu kelompok, dan siswa yang sedang menjalani latihan kerja dengan tujuan agar guru dapat mengevaluasi anak lebih efektif.

Metode kelompok dilakukan untuk siswa lama atas dasar seleksi dengan masalah atau hampir bersamaan, atau dalam melakukan suatu aktivitas untuk tujuan tertentu bagi beberapa siswa sekaligus. Sebelum memulai suatu kegiatan baik secara individual maupun kelompok maka guru harus mempersiapkan terlebih dahulu segala sesuatunya yang menyangkut pelaksanaan kegiatan tersebut. Anak juga perlu dipersiapkan dengan cara memperkenalkan kegiatan dan menjelaskan tujuan pelaksanaan kegiatan tersebut sehingga anak lebih mengerti dan berusaha untuk ikut aktif. Jumlah anggota dalam suatu kelompok disesuaikan dengan jenis aktivitas yang akan dilakukan dan kemampuan guru mengawasi. Sedangkan peninjauan intervensi diartikan sebagai suatu tahap berkelanjutan untuk mengevaluasi dan meninjau kembali rencana intervensi sebelumnya, efektivitas pelaksanaannya, sejauh mana perkembangan yang telah dicapai untuk menuju target hasil akhir. Bilamana dibutuhkan, pada langkah ini dapat dilakukan perubahan terhadap rencana intervensi.

c. Tahap Hasil Akhir

Tahap terakhir pada terapi okupasi adalah hasil akhir (outcome). Hasil akhir disini diartikan sebagai dimensi penting dari kesehatan yang berhubungan dengan intervensi, termasuk kemampuan untuk berfungsi, persepsi kesehatan, dan kepuasaan dengan penuh perhatian. Pada tahap ini ditentukan apakah sudah berhasil mencapai target hasil akhir yang 
diinginkan atau tidak. Jadi hasil akhir dalam bentuk tampilan okupasi, kepuasaan anak, kompetensi aturan, adaptasi, pencegahan, dan kualitas hidup.

Setiap siswa akan melakukan terapi okupasi kelompok harus direncanakan dahulu. Guru melakukan kontrak kepada kelompok. Guru dan kelompok mempertimbangkan tempat, lokasi yang kondusif, alat, dan bahan yang harus disiapkan. Menurut Untari (2006) adapun tahapan aktivitas terapi okupasi kelompok, yaitu:

\section{a. Orientasi}

Orientasi sangat membantu anak untuk mengikuti kelompok terapi. Tujuan orientasi adalah meyakinkan bahwa anak mempunyai orientasi yang baik tentang orang, tempat, dan waktu. Orientasi memerlukan waktu kurang lebih 5 menit. Aktivitas yang dilakukan selama tahapan orientasi adalah guru melakukan orientasi kegiatan.

b. Tahap Pendahuluan (Introduction)

Tahap pendahuluan adalah tahap perkenalan baik dari guru maupun anak. Guru memperkenalkan diri baru kemudian masing-masing anak menyebutkan nama dan alamatnya. Cara yang biasa digunakan adalah dengan melemparkan balon yaitu anak harus menyebutkan nama apabila mendapatkan bola yang telah dilempar. Setiap kali seorang anak selesai memperkenalkan diri, guru mengajak semua anak untuk bertepuk tangan. Tahap pendahuluan memerlukan waktu 5-10 menit.

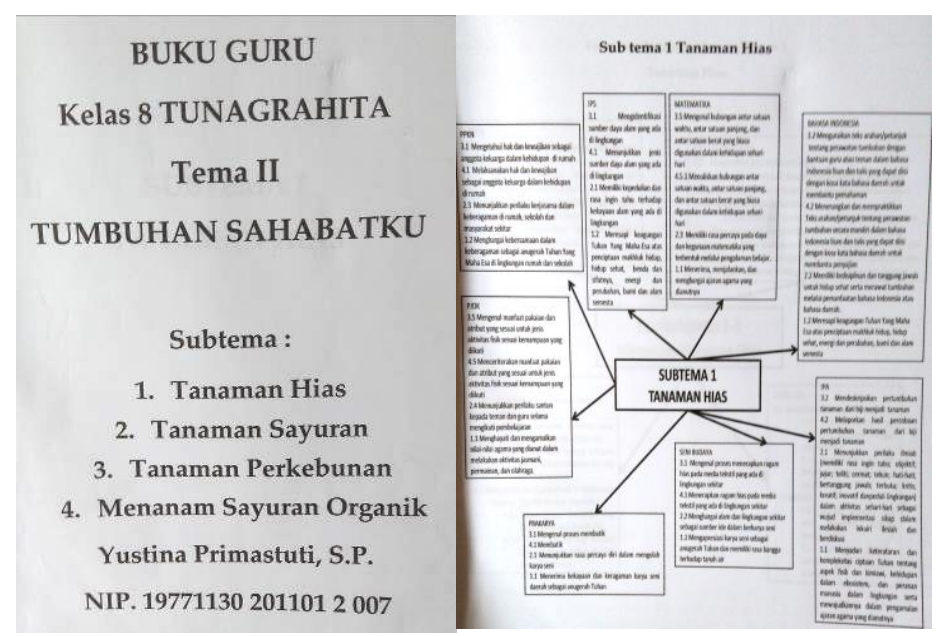

Gambar 3. Contoh buku pegangan guru yang membuktikan pemanfaatan taman untuk kegiatan belajar mengajar 
c. Tahap pemanasan (Warm-up activities)

Setelah melakukan proses memperkenalkan diri, guru mengajak anak untuk aktivitas pemanasan (warmup activities). Tahap ini memerlukan waktu 5-10 menit. Aktivitas yang digunakan adalah latihan fisik sederhana (simple physical exercise). Tujuannya adalah meningkatkan perhatian dan minat siswa melalui gerakan dasar tubuh dan agar siswa mampu mengikuti aturan atau instruksi sederhana seperti berputar, turunkan tangan, dan lain-lain.

d. Tahap aktivitas terpilih (selected activities)

Tahap ini memerlukan waktu 10-20 menit. Mempertimbangkan kebutuhan kognitif, motorik, dan interaksi yang akan dikembangkan. Biasanya aktivitas yang dipilih adalah aktivitas dengan aturan sederhana dan aktivitas yang dilakukan sebaiknya disesuaikan dengan tujuan yang ingin dicapai. Guru memberikan pujian setiap kali siswa selesai melakukan terapi okupasi dengan baik dan mengajak anggota kelompok bertepuk tangan.

e. Tahap Terminasi

Tahap ini menandakan bahwa terapi okupasi akan berakhir. Guru dan anak mengumpulkan material (alat-bahan) bersama-sama dan mengadakan diskusi kecil tentang jalannya proses terapi okupasi.
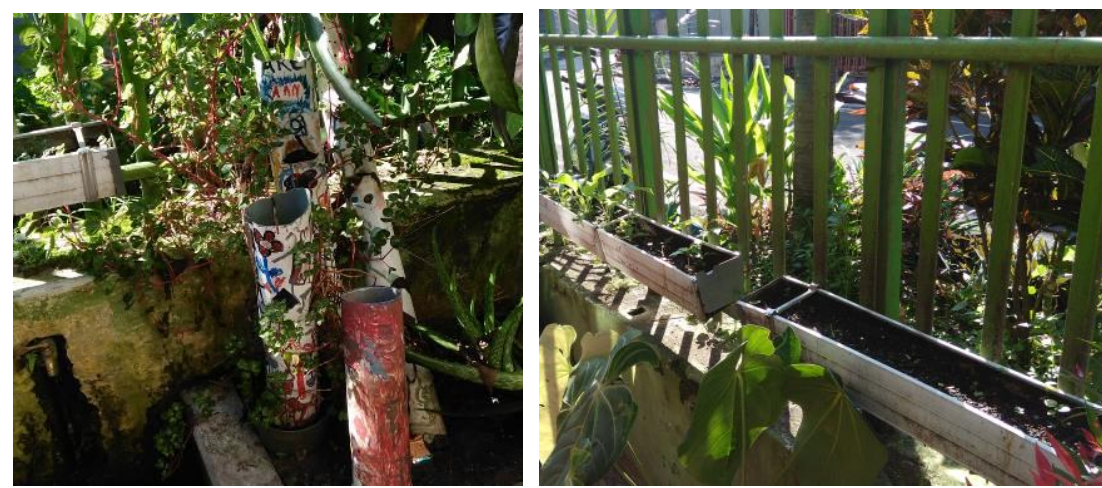

Gambar 4. Hasil karya siswa SLB berupa taman vertikal sayuran hasil dari kegiatan terapi okupasi

\section{KESIMPULAN}

Anak autis ataupun tuna grahita memiliki kecenderungan kurang fokus dan pola pemikiran yang berbeda dengan orang normal, sehingga diperlukan stimulus agar memiliki kepekaan seperti pada umumnya. Di sekolah banyak aktivitas yang dapat dilakukan anak baik di dalam ruang maupun aktivitas yang di luar ruang. Salah satu aktivitas yang dilakukan di luar ruang adalah bermain di taman sekolah. Fungsi dari taman sekolah adalah untuk taman edukasi dimana dapat 
diberikan terapi okupasi pada siswa sekolah. Pihak yang ada di sekolah juga dapat mengarahkan minat dan hobi siswa sehingga tertuang pada hal-hal atau aktivitas yang positif. Terapi okupasi sebagai sarana terapi sensorik, siswa dapat meningkatkan ketajaman inderanya melalui visual, pendengaran, peraba, pengecap dan penciuman, sehingga tercapai titik fokus tertentu yang tidak menyebar. Sebagai sarana edukasi, siswa juga dilatih untuk mengenal lebih dekat tentang tanaman, merawat dan memanennya sehingga mendapatkan pengalaman langsung. Terapi okupasi juga berfungsi dengan menggunakan konsep taman edukasi yang bisa diterapkan di sekolah luar biasa di Kota Malang. Taman edukasi dapat digunakan sebagai sarana terapi okupasi dimana terdapat objek terapi yang meliputi fisik dan mental. Bentuk kegiatan yang dilakukan adalah pengenalan jenis tanaman dan berocok tanam yang menggunakan terapi bermain dan memberikan dampak bersosialisasi semakin berkembang. Adapun tahapan terapi okupasi, antara lain: (1) Tahap Evaluasi, (2) Tahap Intervensi dan (3) Tahap Hasil Akhir. Tahap terapi okupasi kelompok dapat dilakukan dengan (1) Orientasi, (2) Tahap Pendahuluan
(Introduction), (3) Tahap pemanasan (Warm-up activities), (4) Tahap aktivitas terpilih (selected activities) dan (5) Tahap Terminasi.

\section{REFERENSI}

Baskara, M. (2011). Prinsip Pengendalian Perancangan Taman Bermain Anak di Ruang Publik. Jurnal Lanskap Indonesia, 3 (1), pp. 27-34. Haliimah, M., Asikin, D., dan Razziati H. (2014). Taman Sensori pada Ruang Luar Autism Center di Kota Batu.

(Online).

(http://download.portalgaruda.or g/article.php?article. Diakses 13 April 2017

Lauren, G.M. (2012). Desain Taman Lingkungan untuk Anak Usia Sekolah Dasar Di Cluster Callysta Permata, Perumahan Permata Bintaro, Tangerang Selatan. (online) http://repository.ipb.ac.id/handle /123456789/61159. Diakses 21 April 2017.

Nasution. (2004). Metode Research (Penelitian Ilmiah). Jakarta : Bumi Aksara.

Prabowo, B. A. (2015). Sensory Garden Sebagai Konsep Arsitektur Untuk Terapi Autisme. (Online). (http://archadipa.com/index.php 
Jurnal Care Vol .5, No2,Tahun 2017

/2015/07/27/sensory-garden-

sebagai-konsep-arsitektur-untuk-

autisme/). Diakses 13 April 2017

Ramadhani, W.S. (2016). Penerapan

Pembelajaran Outdoor Learning

Process (OLP) Melalui

Pemanfaatan Taman Sekolah

Sebagai Sumber Belajar Materi

Klasifikasi Tumbuhan Untuk

Meningkatkan Hasil Belajar Siswa

SMP. Jurnal Pendidikan Sains, 4 (3),

pp. 1-7.
Tirta \& Putra (2008). Terapi okupasi. http://klinikotcponorogo.co.id/2 012/01/terapi-okupasi.html Untari (2006). Terapi okupasi. http://klinikotcponorogo.co.id/2 012/01/terapi-okupasi.html

Wahyuni, E. (2015). Sekolah Luar Biasa Autis Boyolali Berbasis Alam dengan Penekanan Taman Terapi. (Online). (http://eprints.ums.ac.id/38805/1 /PUBLIKASI.pdf 